\title{
The Eutrophication Status Evaluation of Campus Landscape Water Body
}

\author{
Lin Li*, Chuang Zhan, Nan Li and Haishan Shi \\ College of civil engineering, Hunan University of Technology, zhuzhou, Hunan, China \\ *Corresponding author
}

\begin{abstract}
The eutrophication status evaluation of campus landscape water body had been studied. The results showed that the content of nitrogen and phosphorus were higher than the standard, and the pH was floated in the 7-9, although the transparency had not exceeded the standard, but the content of suspended solids in the water was high. The trophic level of Tongxin lake which $\operatorname{TLI}\left(\sum\right)=\mathbf{4 7 . 4 2}$ was middle nutrition, The trophic level of Tongde lake which $T L I\left(\sum\right)=44.19$ was poor-middle nutrition.
\end{abstract}

Keywords-landscape water; eutrophication; water quality indexes; nutritional status evaluation

\section{INTRODUCTION}

Recently the water quality of landscape had been widely concerned. However, with increasing of population, the quality of landscape had been influenced by human activities; Especially the problems such as eutrophication of landscape water body was serious. The water quality indexes which were total phosphorus (TP), total nitrogen (TN), transparency (SD), $\mathrm{pH}$, chemical oxygen demand (COD) and suspended solids (SS) had been detected in 7-12,2014, and then evaluated the eutrophication of landscape in our school.

\section{MATERIALS AND METHODS}

The water quality of campus landscape in Hunan University of Technology had been investigated and analyzed in nearly half a year. Tongxin lake and Tongde Lake had been respectively made sampling investigation in July, October and December by our group.The sampling points of Q1, T1, T2, T3 as shown figure $1-3$.

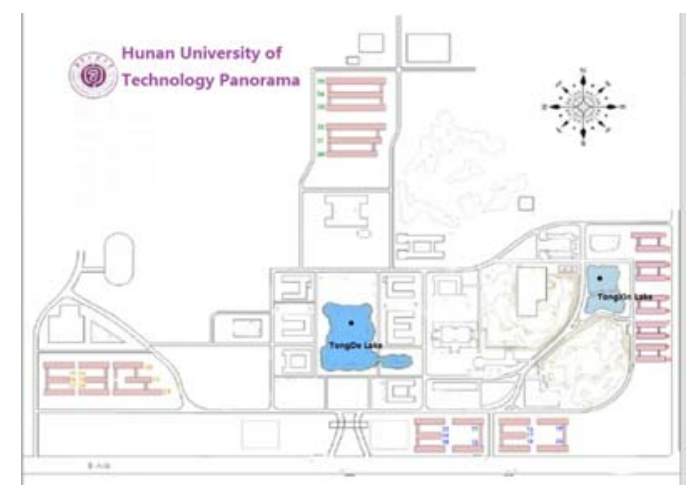

FIGURE I. MAP OF HUNAN UNIVERSITY OF TECHNOLOGY

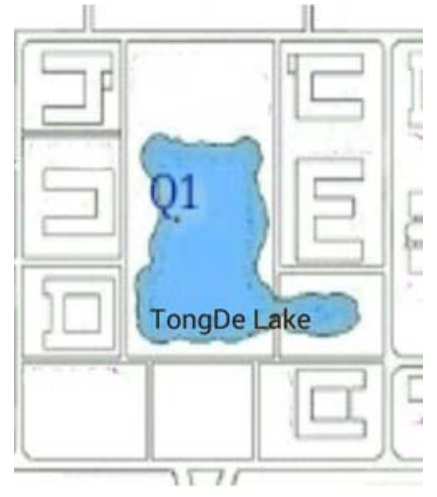

FIGURE II. ONGDE LAKE

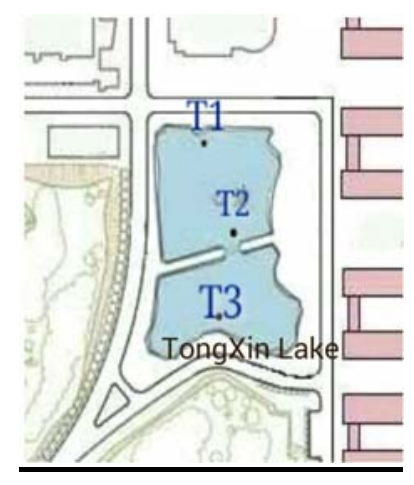

FIGURE III. TONGXIN LAKE

\section{A. Experiment Time and Place}

The experiments started from July to December in 2014, it was for six months.

We chose two artificial lake areas in Hunan University of Technology as the investigation objects, because their water's quality conditions are more consistent with the aim of our research project for the eutrophication investigation of landscape water incampus . Nearly two years, the landscape here has obvious trend of eutrophication.

The sampling points were in Tongxin lake and Tongde Lake (the sampling points respectively as shown in Figure 2, figure 3 showed), the samples were analysis in the biochemical laboratory of our School. 


\section{B. Detection Indexes}

Total phosphorus (TP), total nitrogen (TN), transparency (SD), $\mathrm{pH}$, chemical oxygen demand(COD), suspended solids (SS).

\section{The Criteria and Methods of Nutritional Status Evaluation}

According to the modified Carson index, a series of continuous numbers of $0-100$ was used to grade the trophic state of water, it showed in table 1.

TABLE I. CLASSIFICATION CRITERIA OF NUTRITIONAL STATUS OF WATER BODY.

\begin{tabular}{clcc}
\hline $\begin{array}{c}\text { Comprehensive Carson } \\
\text { index value }\end{array}$ & \multicolumn{1}{c}{ Trophic level } & $\begin{array}{c}\text { Comprehensive Carson } \\
\text { index value }\end{array}$ & Trophic level \\
\hline $0-35$ & Poor nutrition & $66-75$ & Rich nutrition \\
$36-45$ & Poor-middle nutrition & $76-85$ & Severe eutrophication \\
$46-55$ & Middle nutrition & $86-95$ & Abnormal eutrophication \\
\hline $56-65$ & Middle-rich nutrition & $>96$ & \\
\hline
\end{tabular}

According to the nutritional status index, the nutritional status was evaluated by using the correlation weighted index method.

$$
\begin{aligned}
& T H L(\text { chl })=10\left(2.5+\frac{0.996 \ln c(\text { chl })}{\ln 2.5}\right) \\
& T L I(T P)=10\left(9.436+\frac{1.488 \ln c(T P)}{\ln 2.5}\right) \\
& T L I(T N)=10\left(5.453+\frac{1.552 \ln c(T N)}{\ln 2.5}\right) \\
& T L I(S D)=10\left(5.118-\frac{1.778 \ln S D}{\ln 2.5}\right) \\
& T L I(C O D)=10\left(0.109+\frac{2.438 \ln C O D}{\ln 2.5}\right) \\
& T L I\left(\sum\right)=\sum_{i=1}^{m} W_{i} T L I(j)
\end{aligned}
$$

In the formula, $T L I\left(\sum\right)$--icomprehensive nutrition state index; TLI(j)--index of nutritional status of the $\mathrm{j}$ parameter ; $W_{\mathrm{i}}$ --the relative weight of index of nutritional status of the $j$ parameter;

$$
W_{\mathrm{i}}=\frac{r_{i}^{2}}{\sum_{i=1}^{m} r_{i}^{2}}
$$

In the formula, $r_{i}$ stands for correlation coefficient of $\mathrm{J}$ parameter and Chla, $\mathrm{m}$ stands for the number of parameters.

\section{RESUltS AND ANALYSIS}

For water eutrophication, the current general use of the standard was that: nitrogen content in water was over 0.2$0.3 \mathrm{mg} / \mathrm{L}$, phosphorus content $>0.01-0.02 \mathrm{mg} / \mathrm{L}, \mathrm{BOD}>10 \mathrm{mg} / \mathrm{L}$, $\mathrm{pH} 7-9$, the transparency $<0.5 \mathrm{~m}$.

\section{A. The Total Phosphorus(TP) of Water}

From table 2 it was showed that the TP concentration of water were gradually decreased with the increase of the month. The TP concentration of T1, T2, T3 were larger than that of Q1 and all were more than $0.02 \mathrm{mg} / \mathrm{L}$. It showed that the eutrophication of the water in TongXin lake near students' dormitory was more serious than that of TongDe lake. The TP concentration of the two lakes in December were decreased significantly.

TABLE II. THE TOTAL PHOSPHORUS(TP) OF DIFFERENT SAMPLING POINTS (UNIT: MG/L).

\begin{tabular}{rccccccccccccccc}
\hline $\begin{array}{c}\text { Sim } \\
\text { ples }\end{array}$ & & July & & Avg & SD & & October & & Avg & SD & & December & Avg & SD \\
\hline $\mathrm{T} 1$ & 0.245 & 0.365 & 0.382 & 0.331 & 0.061 & 0.239 & 0.385 & 0.39 & 0.338 & 0.070 & 0.115 & 0.134 & 0.109 & 0.119 & 0.011 \\
$\mathrm{~T} 2$ & 0.551 & 0.437 & 0.445 & 0.478 & 0.052 & 0.355 & 0.357 & 0.552 & 0.421 & 0.092 & 0.206 & 0.185 & 0.194 & 0.195 & 0.009 \\
$\mathrm{~T} 3$ & 0.225 & 0.458 & 0.447 & 0.377 & 0.107 & 0.464 & 0.514 & 0.321 & 0.433 & 0.082 & 0.255 & 0.215 & 0.204 & 0.225 & 0.022 \\
$\mathrm{Q} 1$ & 0.226 & 0.245 & 0.301 & 0.257 & 0.032 & 0.235 & 0.352 & 0.295 & 0.294 & 0.048 & 0.056 & 0.141 & 0.065 & 0.087 & 0.038 \\
\hline
\end{tabular}

SD means Standard deviation

\section{B. The Total Nitrogen (TN) of Water}

From table 3 it was showed that the TN concentration of two lakes did not changed obviously from July to October, but the TN concentration changed obviously in December. The
T3's TN concentration of TongXin lake was higher than that of the others. Generally speaking, the TN concentration of TongXin lake was higher than that of TongDe lake, and the concentration of two lakes were all more than the general 
standard of $0.3 \mathrm{mg} / \mathrm{L}$, it showed that both lakes have been polluted.

TABLE III. THE TOTAL NITROGEN(TN) OF DIFFERENT SAMPLING POINTS (UNIT: MG/L).

\begin{tabular}{ccccccccccccccccc}
\hline $\begin{array}{c}\text { Sim } \\
\text { ples }\end{array}$ & & July & & Avg & SD & & October & & Avg & SD & & December & Avg & SD \\
\hline T1 & 0.915 & 1.041 & 0.726 & 0.894 & 0.129 & 1.013 & 0.815 & 0.814 & 0.881 & 0.094 & 0.342 & 0.484 & 0.341 & 0.389 & 0.067 \\
T2 & 0.687 & 1.052 & 0.911 & 0.883 & 0.150 & 0.956 & 0.738 & 0.59 & 0.761 & 0.150 & 0.355 & 0.443 & 0.274 & 0.357 & 0.069 \\
T3 & 1.121 & 1.241 & 1.026 & 1.129 & 0.088 & 1.241 & 1.041 & 1.312 & 1.198 & 0.115 & 0.525 & 0.635 & 0.605 & 0.588 & 0.046 \\
Q1 & 0.717 & 0.535 & 0.624 & 0.625 & 0.074 & 0.677 & 0.721 & 0.745 & 0.714 & 0.028 & 0.356 & 0.474 & 0.395 & 0.408 & 0.049 \\
\hline
\end{tabular}

\section{The Water Transparency}

From table 4 it showed that the water transparency of the two lakes were more than the $0.5 \mathrm{~m}$ standards, which means the eutrophication has few effect on the water transparency. And with the change of time, there was not obviously changes in the water transparency, there were little difference on the water transparency between TongXin lake and TongDe lake.

TABLE IV. THE WATER TRANSPARENCY OF DIFFERENT SAMPLING POINTS (UNIT: M).

\begin{tabular}{ccccccccccccccccccc}
\hline Simples & & July & & Avg & SD & & October & & Avg & SD & \multicolumn{2}{c}{ December } \\
\hline T1 & 0.53 & 0.54 & 0.57 & 0.55 & 0.017 & 0.79 & 0.83 & 0.82 & 0.81 & 0.017 & 0.66 & 0.74 & 0.69 & 0.70 & 0.033 \\
T2 & 0.63 & 0.61 & 0.71 & 0.65 & 0.043 & 0.73 & 0.75 & 0.66 & 0.71 & 0.039 & 0.77 & 0.71 & 0.69 & 0.72 & 0.034 \\
T3 & 0.59 & 0.53 & 0.62 & 0.58 & 0.037 & 0.74 & 0.65 & 0.7 & 0.70 & 0.037 & 0.65 & 0.76 & 0.64 & 0.68 & 0.054 \\
Q1 & 0.71 & 0.64 & 0.68 & 0.68 & 0.029 & 0.84 & 0.68 & 0.81 & 0.78 & 0.069 & 0.74 & 0.73 & 0.67 & 0.71 & 0.031 \\
\hline
\end{tabular}

\section{The Water $\mathrm{pH}$}

From table 5 it showed that the water of TongXin lake was weakly alkaline, the water of Tongde lake was neutral. And in

the investigation of 6 months, the $\mathrm{pH}$ change not obviously, acidity and basicity were stable.

TABLE V. THE WATER PH OF DIFFERENT SAMPLING POINTS .

\begin{tabular}{cccccccccccccccc}
\hline Simples & & July & & Avg & SD & \multicolumn{3}{c}{ October } & Avg & SD & \multicolumn{3}{c}{ December } & Avg & SD \\
\hline T1 & 8.5 & 9 & 8.8 & 8.77 & 0.205 & 8 & 7.3 & 7.5 & 7.60 & 0.294 & 7.8 & 7.9 & 8.5 & 8.07 & 0.309 \\
T2 & 9 & 7.5 & 8.5 & 8.33 & 0.624 & 7.8 & 7.5 & 8.5 & 7.93 & 0.419 & 8.3 & 7.5 & 8 & 7.93 & 0.330 \\
T3 & 8.4 & 8 & 7.6 & 8.00 & 0.327 & 7.6 & 8 & 7 & 7.53 & 0.411 & 8 & 8 & 7.7 & 7.90 & 0.141 \\
Q1 & 7.8 & 7.2 & 8 & 7.67 & 0.340 & 7.1 & 6.8 & 6.5 & 6.80 & 0.245 & 7 & 7.5 & 6.8 & 7.10 & 0.294 \\
\hline
\end{tabular}

\section{E. The Chemical Oxygen Demand (COD) of Water}

From table 6 and fig 8 it showed that the COD index of the two lakes in December was lower than than of in July and
October, it indicated that various reaction degree of the water body was decrease with temperature. But the COD of TongXin lake was higher than of TongDe lake.

TABLE VI. THE WATER COD OF DIFFERENT SAMPLING POINTS (UNIT: MG/L).

\begin{tabular}{rrrrrrrrrrrrrrrr}
\hline $\begin{array}{c}\text { Sim } \\
\text { ples }\end{array}$ & & July & & Avg & SD & \multicolumn{2}{c}{ October } & Avg & SD & December & Avg & SD \\
\hline T1 & 16.5 & 16.7 & 17.1 & 16.8 & 0.249 & 16.5 & 17.3 & 18.4 & 17.4 & 0.779 & 9.8 & 11 & 9.5 & 10.1 & 0.648 \\
T2 & 17.6 & 18.2 & 17.5 & 17.8 & 0.309 & 17.9 & 18.4 & 18 & 18.1 & 0.216 & 10.9 & 8.7 & 9 & 9.5 & 0.974 \\
T3 & 15.6 & 14.9 & 18.3 & 16.3 & 1.466 & 16.9 & 16.5 & 16.7 & 16.7 & 0.163 & 8.3 & 9.5 & 8.7 & 8.8 & 0.499 \\
Q1 & 13.6 & 14.5 & 14.3 & 14.1 & 0.386 & 13.6 & 15.5 & 13.7 & 14.3 & 0.873 & 7.6 & 5.8 & 6.4 & 6.6 & 0.748 \\
\hline
\end{tabular}

\section{F. The Suspended Solids (SS) of Water}

From table 7 it was showed that the concentration of suspended substance in water decreased with the winter' entering, temperature affected on the biological activity in water, and it also can explain that the water body was clearer at low temperature than that of at high temperature. Generally speaking, the suspended solids in TongXin lake was higher than TongDe lake. 
TABLE VII. THE SUSPENDED SOLIDS(SS) OF WATER IN DIFFERENT SAMPLING POINTS (UNIT: MG/L).

\begin{tabular}{cccccccccccccccc}
\hline $\begin{array}{c}\text { Sim } \\
\text { ples }\end{array}$ & & July & & Avg & SD & & October & Avg & SD & \multicolumn{2}{c}{ December } & Avg & SD \\
\hline T1 & 21.8 & 18.3 & 19.7 & 19.93 & 1.438 & 19.7 & 18.4 & 18.3 & 18.80 & 0.638 & 15.6 & 16.3 & 17.1 & 16.33 & 0.613 \\
T2 & 17.6 & 18.9 & 16.5 & 17.67 & 0.981 & 17.6 & 14.3 & 15.7 & 15.87 & 1.352 & 14.3 & 15.5 & 13.9 & 14.57 & 0.680 \\
T3 & 23.4 & 22.1 & 17.2 & 20.90 & 2.670 & 19 & 16.4 & 17.4 & 17.60 & 1.071 & 15.1 & 14.2 & 18.1 & 15.80 & 1.667 \\
Q1 & 15.4 & 16.9 & 16.4 & 16.23 & 0.624 & 16.6 & 14.3 & 13.5 & 14.80 & 1.314 & 9.8 & 10.2 & 8.7 & 9.57 & 0.634 \\
\hline
\end{tabular}

\section{G. The Criteria and Methods of Nutritional Status Evaluation}

The average data of the two lake in each month had been substituted into the above formula and the results were: $\operatorname{TLI}\left(\sum\right)=47.42$ of Tongxin lake, $\operatorname{TLI}\left(\sum\right)=44.19$ of Tongde lake. According the above referenced nutritional status evaluation and classification standards, the trophic level of Tongxin lake was middle nutrition, and the trophic level of Tongde lake was poor-middle nutrition. From our investigation and study of the artificial lake pollution observations showed that, because of the cleanup work it was achievely effectted the water quality, which was in middle nutritional status.

\section{CONCLUSIONS}

Through the observation and the experimental data of the water body in the past few months, the analysis showed that : the content of nitrogen and phosphorus were higher than the standard, and the $\mathrm{pH}$ was floated in the 7-9, although the transparency had not exceeded the standard, but the content of suspended solids in the water was high. Except $\mathrm{pH}$ had not changed much, other indicators were reduced with decreasing of temperature. Compared with these five indicators in three months it indicated that: The various indicators of the TongDe lake which was far from the dormitory building were lower than that of TongXin lake, and with the decreasing of the temperature, the degree of eutrophication of the water body was reduced.

Due to the attention of the school to the landscape water, it has been carried out the transformation of governance in the half time of the year. These may lead to a deviation of the processing of the final data.

\section{ACKNOWLEDGMENT}

This research was financially supported by the general project of Hunan province department of education(No. 15C0385); The funding for Research study and innovative experimental project Foundation of Hunan University of Technology (No.011819|0002080); The funding for scientific research of Hunan University of Technology (No. 040702|0230218)

\section{REFERENCES}

[1] The Water and Wastewater Monitoring Analysis Method Editorial Committee. The Water and Wastewater Monitoring Analysis Method .Beijing: China Environmental Science Press, 2002

[2] Wang M C, Liu XQ, Zhang JH, Lake eutrophication evaluation method and grading standards, China Environmental Monitoring,2002,18(5):4749.
[3] Peng ZR,Chen J,Jiang $M$, et al. Investigation and evaluation of nutritional status of water quality in Gehu Lake, Journal of Shanghai Fisheries University, 2007,16 (3): 252-258

[4] Shen BL, Zhang WY, Hu XQ, Tong Y, et al. Evaluation of the eutrophication degree of small urban landscape water body, Anhui Agricultural Sciences, 2011,39 (23): 14321-14325.

[5] Jin XC, Tu QY, Lake eutrophication survey specification, Beijing: Science Press, 1990:286-295.. 